

\title{
Intransigência, făácia e ilusão: a reação conservadora contra a previdência e seguridade social no Brasil $^{1}$
}

\author{
Intransience, phalacy and illusion: The \\ conservative reaction against social security \\ system in Brozil
}

Ignacio Godinho Delgado*

\begin{abstract}
Resumo
O artigo analisa a reforma da previdência impulsionada pelo presidente Bolsonaro. Seu primeiro propósito é identificar os elementos comuns à retórica conservadora e reacionária que acompanha, no Ocidente e no Brasil, todas as medidas que envolveram o progresso social e a expansão da cidadania, agora dirigida contra a seguridade social brasileira, instituída na Carta de 1988. Também são apresentados dados e argumentos produzidos pela Associação Nacional dos Auditores Fiscais da Receita Federal do Brasil (ANFIP), principalmente, e autores que têm se dedicado ao tema, que afirmam a falácia do diagnóstico sobre a crise da previdência. Além disso, aponta que tal diagnóstico não considera outras possibilidades de lidar com os possíveis dilemas atuariais da previdência social, por estar eivado de um certo malthusianismo, que negligencia o impacto do desenvolvimento tecnológico sobre o mercado de trabalho e o nível de renda global da economia
\end{abstract}

Palavras-chave: previdência, seguridade social, Brasil, retórica conservadora.

\begin{abstract}
The article analyzes the pension reform promoted by President Bolsonaro. Its first purpose is to identify the elements common to the conservative and reactionary rhetoric that accompanies, in the West and Brazil, all the measures that involved social progress and the expansion of citizenship, now directed against Brazilian social security, instituted in the 1988 Charter ( section 2). Next, we present data and arguments produced by the National Association of Tax Auditors of the Federal Revenue of Brazil (ANFIP), mainly, and authors who have been dedicated to the theme, who affirm the fallacy of the diagnosis of the social security crisis. Moreover, it points out that such a diagnosis does not consider other possibilities to deal with the possible actuarial dilemmas of social security, because it is riddled with a certain malthusianism, which neglects the impact of technological development on the labor market and the overall income level of the economy.
\end{abstract}

Keyword: social security, Brazil, Conservadorism.

\footnotetext{
* Professor Titular aposentado da Universidade Federal de Juiz de Fora (UFJF). Graduou-se em História pela UFJF (1981). É membro do Comitê Gestor do Instituto Nacional de Ciência e Tecnologia - Políticas Públicas, Estratégias e Desenvolvimento (INCT-PPED). Desde abril de 2016, exerce a direção do Centro Regional de Inovação e Transferência de Tecnologia (CRITT) e da Diretoria de Inovação da UFJF. E-mail: ignácio.delgado@ufffedu.br.
} 


\section{INTRODUÇÃO}

Neste artigo não se descreve em detalhes as perversidades da proposta da "Nova Previdência" de Bolsonaro e Guedes, evidenciadas num sem número de publicações e pronunciamentos de entidades diversas, movimentos sociais, forças políticas progressistas e intelectuais. Seu primeiro propósito é identificar os elementos comuns à retórica conservadora e reacionária que acompanha, no Ocidente e no Brasil, todas as medidas que envolveram o progresso social e a expansão da cidadania, agora dirigida contra a seguridade social brasileira, instituída na Carta de 1988 (seção 2). Em seguida, são apresentados dados e argumentos produzidos pela Associação Nacional dos Auditores Fiscais da Receita Federal do Brasil (ANFIP), principalmente, e autores que têm se dedicado ao tema, que afirmam a falácia do diagnóstico sobre a crise da previdência. Além disso, aponta que tal diagnóstico não considera outras possibilidades de lidar com os possíveis dilemas atuariais da previdência social, por estar eivado de um certo malthusianismo, que negligencia o impacto do desenvolvimento tecnológico sobre o mercado de trabalho e o nível de renda global da economia (seção 3).

Uma avaliação preliminar da promessa de dinamização do mercado de capitais, do investimento e do emprego com o crescimento da previdência privada, sucedânea da implantação do sistema de capitalização, é efetuada com alguns elementos de comparação com outros países, em meio ao processo de financeirização observado na ordem capitalista global, com peso destacado na economia brasileira (seção 4). À guisa de conclusão discorre-se sobre as conexões entre tempo livre, cidadania e desenvolvimento, levando em conta a "reforma trabalhista"e a "Nova Previdência Social", que afetam de forma crucial as relações de trabalho e o sistema brasileiro de aposentadoria e pensões.

\section{A RETÓRICA DA INTRANSIGÊNCIA}

Alberto Hirschman (1992) assinalou, certa feita, que a retórica conservadora reage desde a Revolução Francesa com três argumentos, diante dos avanços políticos e sociais que têm marcado a expansão da cidadania no mundo contemporâneo: futilidade, perversidade, ameaça. Sinteticamente, mudanças sociais seriam por vezes fúteis, porque promovem mudanças já em curso a custos elevados, ou por não produzirem os efeitos que perseguem. Perversas, porque tenderiam a acentuar os problemas que buscam resolver ou gerar outros. Por fim, representam ameaças porque podem provocar desequilíbrio na ordem social ou colocar em risco direitos consagrados.

Hirschman destaca as críticas conservadoras à Revolução Francesa, à expansão do sufrágio, aos impactos do Welfare State. Respectivamente, uma futilidade porque, no Antigo Regime, as mudanças que a Revolução promoveu já estariam se desenvolvendo em ritmo seguro sem as consequências trágicas do terror revolucionário. Por seu turno, 
a extensão do sufrágio foi recepcionada num primeiro momento, pelo pensamento conservador e liberal, como uma ameaça à propriedade privada e um risco para as liberdades - por pavimentar o caminho para um despotismo de novo tipo e um convite à busca de soluções autoritárias, dado o pânico das elites diante de sua iminente espoliação - ou, inversamente, um expediente fútil, porquanto incapaz de impedir o inexorável domínio político de grupos minoritários, a partir do entendimento de que as massas são dotadas de congênita irracionalidade. Por fim, o Welfare State, que de certa forma é a coroação das promessas da combinação de liberdade, igualdade e solidariedade, nos limites da ordem capitalista,foi saudado em seu nascedouro como o caminho da servidão, uma ameaça aos direitos individuais, em virtude da acentuação do papel do Estado, que interviria indevidamente no livre jogo do mercado, reduzindo sua eficiência alocativa, num arranjo inútil e perverso, acusado de provocar dissipação e preguiça sem resolver o problema da pobreza.

Entre o final da Segunda Guerra Mundial e a crise de 1973 tais argumentos perderam vitalidade. Em boa medida, devido à ameaça comunista, pelos trinta anos de gloriosos vividos pelo capitalismo, em maior ou menor escala, no seu centro. No âmbito de um arranjo de colaboração entre as classes respeitado por todas as forças políticas do espectro ideológico nas democracias ocidentais, assistiu-se a uma virtuosa combinação de índices acentuados de dinamismo econômico e tecnológico com a expansão das liberdades democráticas, dos direitos em suas múltiplas dimensões, a redução da desigualdade e a promoção do bem-estar social. Mesmo nos países periféricos e semiperiféricos, algumas trajetórias desenvolvimentistas (ainda que sem produzir, de forma homogênea, impactos na redução da desigualdade, por vezes até acentuando-a) conheceram mudanças estruturais profundas, com incremento da industrialização e da urbanização que, por si só, foram capazes de elevar certos indicadores de bem-estar, além de ensejarem a constituição de sistemas de proteção social de alcance variado.

$\mathrm{Na}$ trajetória brasileira, a retórica da intransigência apontada por Hirschman esteve presente na reação a todos os passos de nossa tortuosa, lenta e incompleta conquista do patamar civilizatório que, no centro do sistema capitalista, se constituíra nas décadas seguintes à Segunda Guerra. Antes dela, o fim da escravidão foi apontado por muitos como um risco para a economia brasileira; a consolidação dos direitos do trabalho por Vargas, após décadas de luta operária, de que inviabilizaria a produção industrial; as tímidas reformas propostas por Goulart seriam a porta aberta para o comunismo internacional; a Constituição de 1988 tornaria o país ingovernável; a bolsa família alimentaria a ociosidade; as cotas estimulariam um racismo inexistente no país da democracia racial e minariam a meritocracia; a ampliação dos gastos sociais geraria explosiva crise fiscal do Estado e impediria que o livre jogo das forças de mercado cumprisse seu papel na elevação do investimento e na geração de emprego.

É esta mesma retórica que alimenta hoje as ações de desmonte do Estado de Bem-Estar Social que construímos a duras penas e de forma incompleta desde a 
Constituição de 1988. Durante todo esse período sua consolidação, expressa na materialização institucional e no aporte pleno dos recursos previstos na Constituição para a Seguridade Social, não foi efetivada plenamente pelos governos que se seguiram à promulgação da Carta (Fagnani, 2017). Não foi criada uma agência pública, nem o conselho pertinente responsável por gerir a Seguridade Social em suas três dimensões (previdência social, saúde e assistência); a regulamentação de seus dispositivos seguiu de forma lenta no Executivo e no Parlamento; o SUS esteve permanentemente subfinanciado; o orçamento da seguridade - que, constitucionalmente, deveria agrupar as contribuições previdenciárias, o CSLL, o Cofins, as receitas de prognósticos de loterias e dos tributos incidentes sobre o importador de bens e serviços- foi sempre retalhado entre diversos organismos e sujeito, à exceção das receitas propriamente previdenciárias, à apropriação de parte de seus recursos pelo Estado, através dos dispositivos de desvinculação de receitas para o pagamento dos serviços da dívida pública.

Ainda assim, a criação da seguridade social no Brasil teve impactos positivos nos indicadores de saúde da população, através da ação do SUS, e na redução das desigualdades, mesmo que tímida, em especial por força dos benefícios previstos na assistência social como o BPC, processo aprofundado com a criação do Bolsa família, da política de valorização do salário mínimo, das medidas de promoção do acesso à educação dos mais pobres e das políticas de ação afirmativa dos governos de centroesquerda que se instalaram no topo do aparelho de Estado a partir de 2003. Consoante com uma tradição conciliadora que, segundo certas interpretações, marca a trajetória política brasileira, o país parecia trilhar um caminho em que se podia mirar, devagar, mas continuamente, o alcance daquele patamar civilizatório que institui a comunidade de sentimento e o compartilhamento de um status a integrar todos os indivíduos na cidadania. Uma sensação de pertencimento e de identidade entre os brasileiros que não seria mais derivada meramente da unidade linguística ou superficialmente vivida, ainda que de forma intensa, em territórios do lúdico.

Sabe-se que a conciliação, quando orientada para a promoção da igualdade entre os brasileiros, de fato nunca foi exatamente um traço do caráter de nossas elites. Atestam isso, no plano dos eventos políticos de maior impacto desde o fim do Estado Novo, o cerco a Vargas até o seu suicídio (fortemente motivado pela insatisfação empresarial com a elevação do salário mínimo) e o golpe de 1964 (que teve na reação à reforma agrária um de seus motes fundamentais). No plano da vida cotidiana, a conciliação só existe, para os segmentos endinheirados e as parcelas deslumbradas e esnobes da classe média, quando os pobres se colocam, por assim dizer, no seu devido lugar. Ainda assim, durante os 25 anos que se estenderam de 1988 a 2013 (mais tempo que os 19 anos transcorridos entre 1945 e 1964) algo de novo se insinuava na vida brasileira. Tivemos a crise do impedimento de Collor, o experimento neoliberal de Fernando Henrique Cardoso, as heterodoxias jurídicas do chamado mensalão, o cerco contínuo da mídia conservadora aos governos de centro-esquerda, mas 
caminhávamos adiante, com eleições regulares e melhora progressiva das condições de vida da população brasileira, em boa medida assegurada pelo sistema de proteção social criado em 1988, além da emergência de um sentimento de comunhão e de orgulho nacional poucas vezes visto no Brasil fora das disputas de Copa do Mundo e da participação em festas populares como o carnaval.

Em meio à retração da atividade econômica e do conflito distributivo que a acompanhou a partir de 2011, bem como à pressão de organismos internacionais, especialmente ligados aos EUA (receosos do protagonismo brasileiro na América do Sul ena articulação dos BRICS, reforçado pelas possibilidades abertas com a descoberta do Pré-Sal) tudo começa a desmoronar. Retorna com força o discurso de que a recuperação brasileira passa pela redução do Custo do Trabalho e da mitigação do papel do Estado na promoção do desenvolvimento e na garantia de proteção social, essa última associada à "rigidez" das relações de trabalho e à presença de um sistema de proteção social "generoso", responsabilizado pela "crise fiscal" do Estado brasileiro. Os remédios para tais males seriam as velhas receitas de privatização, esvaziamento do papel dos bancos públicos e dinamização do mercado de capitais, a "reforma trabalhista" e, com destaque agora, a "Nova Previdência", para corrigir os "excessos da seguridade social" e criar um ambiente capaz de proporcionar a retomada do crescimento econômico e a geração de empregos. Consideremos adiante essa última prescrição.

\section{CRISE DA PREVIDÊNCIA?}

A proposta de instituição de uma "Nova Previdência" se ancora em dois argumentos básicos:

a) A seguridade social e a previdência em especial seriam insustentáveis, portanto é preciso alterá-las para que uma catástrofe não se realize à frente, inviabilizandoas e prejudicando seus futuros beneficiários (Tesouro Nacional, 2017). É preciso deter a ameaça para impedir a perversidade.

b) A mudança do regime de repartição simples para o regime de capitalização não só conferiria mais segurança aos beneficiários da previdência, como criaria condições para a dinamização do mercado de capitais no Brasil, elevando a poupança, o investimento e o emprego².

Vamos considerarnesta seção apenas o argumento que aponta a insustentabilidade da previdência social e da seguridade. Adiante abordamos a proposta de instituição do sistema de capitalização.

Um primeiro aspecto a destacar é a evidente manipulação das fontes de receita e das despesas efetuadas na contabilidade apresentada pelo Executivo quando trata da seguridade social. Tomemos, inicialmente, apenas a previdência social. $\mathrm{Na}$ Constituição de 1988, é dito que a previdência social, como parte da seguridade, "será organizada sob a forma de regime geral, de caráter contributivo e de filiação 
obrigatória, observados critérios que preservem o equilíbrio financeiro e atuarial..." (CF, art 201, Título VIII, Capítulo II, Seção III). Os regimes próprios de servidores civis da União e de todos os entes federativos estão previstos no artigo 40 da CF (Título III, Capitulo VII, Seção II) como parte da Organização do Estado. Eles não fazem parte da Seguridade Social, assim como os salários percebidos por militares inativos ${ }^{3}$. Não faz sentido, pois, serem apresentados como parte das despesas componentes do déficit da previdência social, no âmbito da seguridade social. No serviço público federal, a convergência com o regime geral foi completada em 2012, com dois elementos adicionais, a contribuição efetuada pelos inativos e a possibilidade de reversão das aposentadorias. Já os militares, pela especificidade da carreira, até hoje não dispõem de regime próprio. Para buscar alguma legitimação na proposta que encaminhou ao congresso da "Nova Previdência", que vai alcançar fundamentalmente o regime geral, o atual governo anunciou a criação de um regime próprio para os militares. Todavia, tal proposta veio combinada a mudanças na carreira que, no limite, elevam os gastos do poder público e têm impacto reduzido no equacionamento das dificuldades fiscais do Estado brasileiro ${ }^{4}$.

Ainda em relação à previdência social, nos boletins mensais publicados sobre seu desempenho pelos órgãos da Previdência, do Tesouro Nacional e pelo Banco Central, segundo a ANFIP (2018), são desconsideradas as renúncias que afetam diretamente a arrecadação, bem como a contribuição do Estado, dentro do modelo tripartite do sistema de repartição adotado em todos os países que o instituíram. No caso brasileiro, ao estabelecer o orçamento da Seguridade Social, a CF definiu que suas fontes de receita deveriam cobrir, sem distinção, suas três dimensões (previdência, saúde e assistência). Os aportes do governo federal para o sistema dispõem, pois, de base definida. Em 2005, tais aportes para custeio do regime geral eram de $25,7 \%$ das despesas. Em 2011, de 12,6\%, em função das políticas de apoio à formalização do mercado de trabalho. Em 2017, com o país em recessão e já sob o impacto do declínio da formalização favorecido pela "reforma trabalhista", alcançou 32,7\%. Ainda assim, um valor inferior à média dos países europeus da OCDE, de 36\%. (ANFIP, 2018, 157). Se forem incluídas nas receitas as compensações pela desoneração da folha de pagamentos e outras renúncias fiscais, o cenário é bem diverso, com exigências menores de participação de outras receitas da seguridade para sustentar a previdência (ver tabelas 1 e 2).

No subsistema urbano da previdência social, incorporadas as compensações pelas desonerações e as renúncias fiscais às receitas, o saldo positivo é considerável, entre 2008 e 2015, em seguida ao resultado negativo, apresentado na tabela 3 da ANFIP, de 2005. Após 2015 , os saldos negativos reaparecem na medida do agravamento da crise econômica e da degradação do mercado de trabalho. 


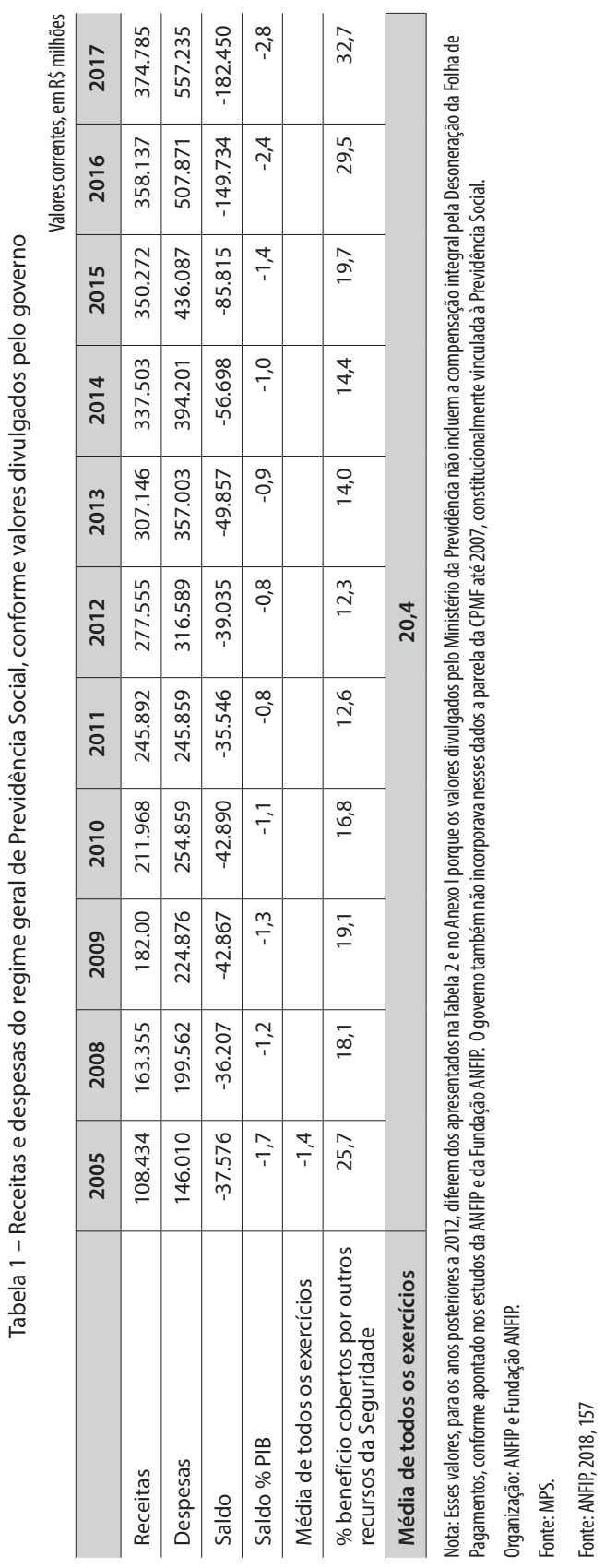




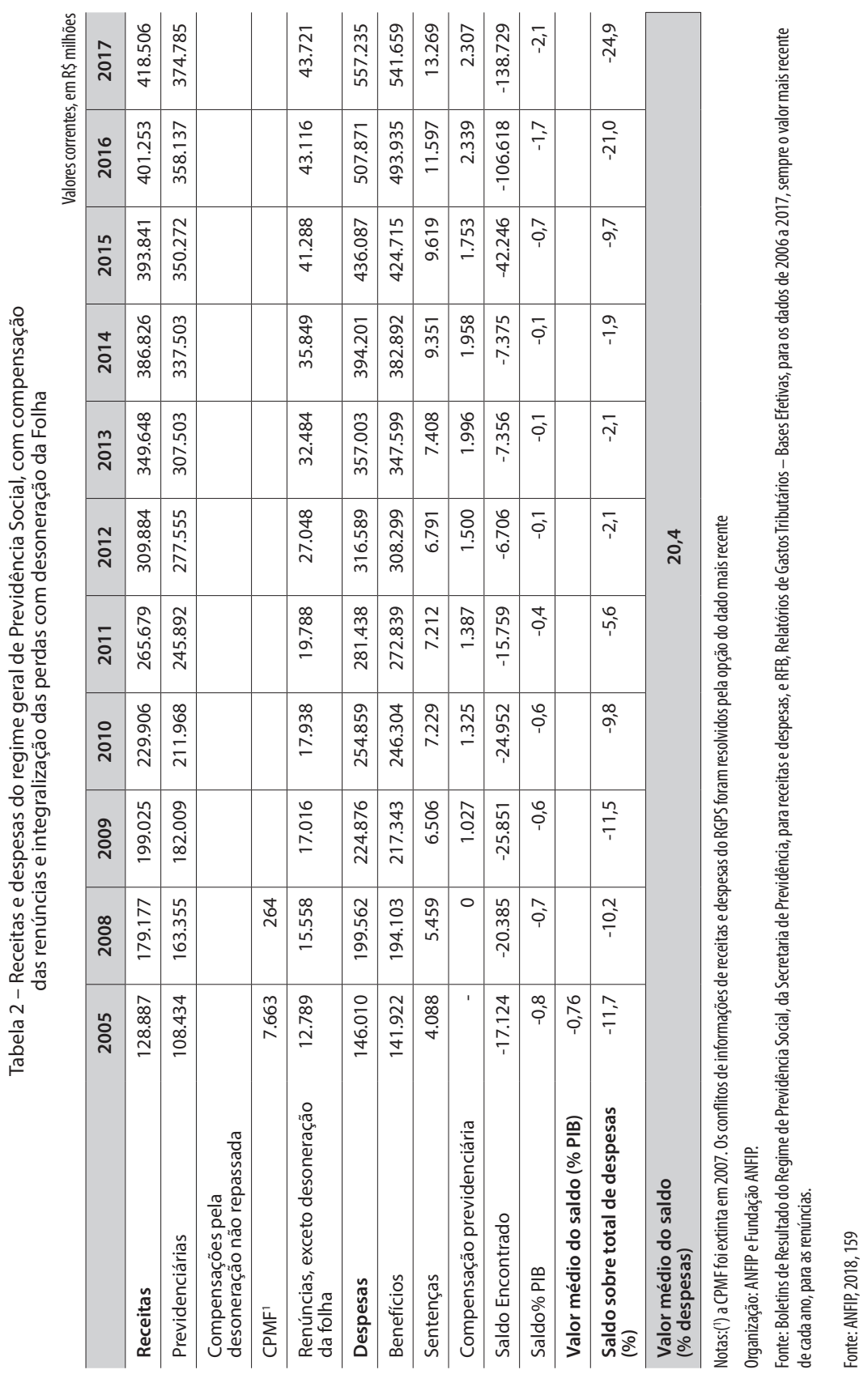




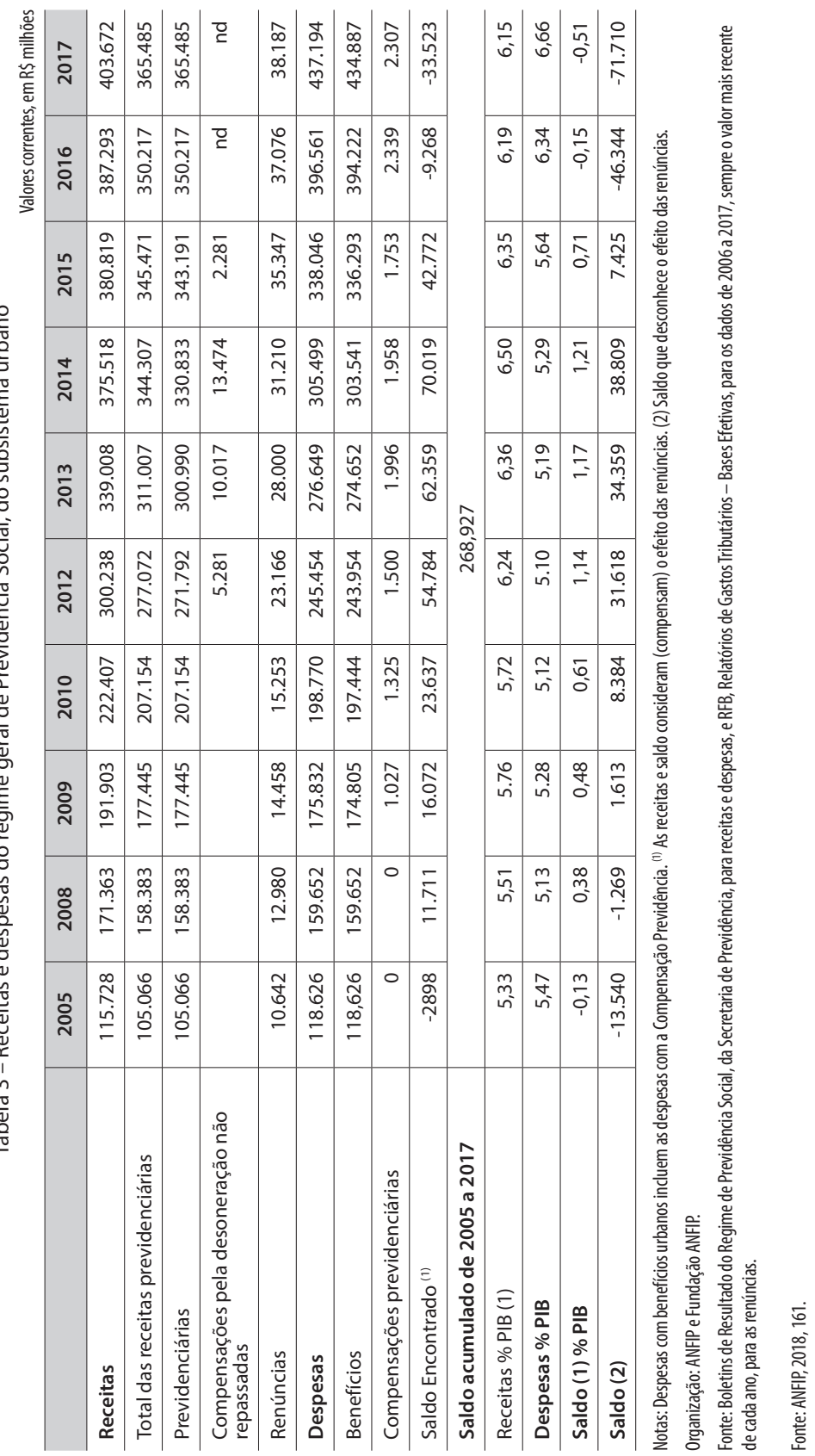


Já o desempenho do subsistema rural, cujo custeio está vinculado a alíquotas sobre a comercialização da produção, foi afetado pela imunidade do setor exportador (o mais bem aquinhoado do segmento), pela enorme sonegação, pela informalidade das relações de trabalho e por medidas pontuais, como o fim da CPMF que, em parte, era destinada ao custeio da previdência rural, num montante que representava o dobro de suas contribuições específicas, sem que houvesse substituição definida de receita (ANFIP, 2018, 169). Ainda assim, com base no princípio solidário que fundamenta a previdência social no âmbito da seguridade social, as receitas do subsistema urbano e de outras fontes da seguridade seriam suficientes para cobrir os déficits da área rural.

Um estudo divulgado na publicação de ANFIP, Dieese e Plataforma Política Social (Puty, Francês, Carvalho, Silva da Silva e Alves da Silva, 2017) observa que as projeções do governo federal sobre a arrecadação previdenciária têm reiteradamente incorrido em erros, em geral subestimando receitas e elevando despesas, por se fixarem em variáveis constantes, que não consideram a dinâmica do mercado de trabalho. Assim, com base nas Leis de Diretrizes Orçamentárias (LDO) de 2002 a 2015, observam-se disparidades expressivas que são mais significativas quanto mais distante são as datas projetadas, o que torna tais estimativas incongruentes para a construção de cenários futuros longínquos ${ }^{5}$. As variáveis consideradas são, no "módulo demográfico", as taxas de urbanização, de participação e de desemprego, na "entrada" do sistema, enquanto as "saídas" são os empregados rurais e urbanos com carteira assinada. No "módulo receita", as variáveis relevantes são o salário médio e as alíquotas previdenciárias, que afetam as contribuições e as receitas. No "módulo despesa", os parâmetros previdenciários na "entrada", são a idade mínima, o teto, o piso, o fator previdenciário, bem como a probabilidade de o empregado entrar em benefício ou do benefício se extinguir (com sua morte) e o valor médio dos benefícios por tipo de rendimento; na "saída" são relevantes o número de concessões de benefícios, seu estoque e despesas. Concluem os autores após análise dos erros na série analisada:

A indisponibilidade dos dados previdenciários, a nebulosidade nas estratégias de cálculo e o nível de erro do previsto em relação ao experimentado, acima de patamares razoáveis, são agravados pela existência de dados díspares em distintas fontes oficiais e tratamento probabilístico inadequado para determinadas variáveis chaves para que se façam previsões prestáveis. Parte considerável das falhas de projeção vem do modo como são tratadas as variáveis do mercado de trabalho. Ao se tratarem como constantes algumas das variáveis fundamentais do mercado de trabalho ignoram-se as profundas mudanças ocorridas no período recente. Essa desproporcionalidade entre a variação dos parâmetros de entrada para cálculo das receitas e despesas gera incerteza na qualidade das projeções. Enquanto as receitas são fortemente impactadas pelos parâmetros de mercado, tomados como constantes (nas projeções do governo as taxas de participação e formalização não crescem ao longo dos anos), as despesas são fortemente impactadas pela demografia projetada pelo IBGE (na previsão do governo, a relação de dependência de pessoas idosas cresce ao longo dos anos, apesar de se saber que a taxa de crescimento da população idosa acima de 60 anos é decrescente no mesmo período) ${ }^{6}$. "Leis, como salsichas, deixarão de inspirar respeito na medida em que soubermos como são fei- 


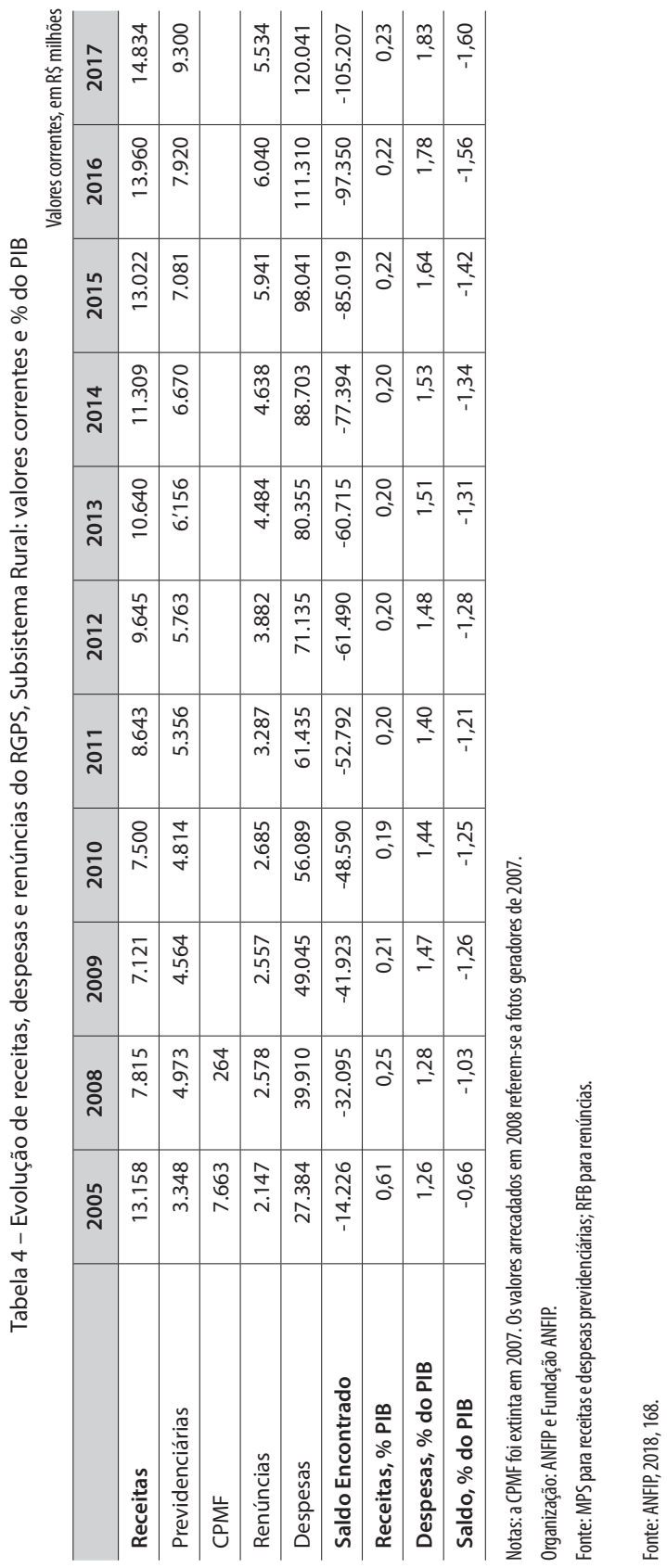


tas", frase que Bismarck não disse, vem bem a calhar nesse caso. Esses métodos obscuros e instrumentos ineficazes estão guiando e visam a dar legitimidade (falsa) ao discurso oficial que propõe retirar direitos de milhões de brasileiros. Faz-se urgente que o Parlamento e as organizações de representação política dos trabalhadores reivindiquem e obtenham maior controle público sobre as informações produzidas pelo governo. O economista americano Charles F. Manski - notório estudioso dos métodos de avaliação de políticas públicas baseados em modelos que apenas fantasiam a própria infalibilidade, sem reconhecer suas muitas lacunas lógicas - tem defendido que para o bem do público é melhor admitirmos honestamente nossas dúvidas, em vez de fabricar certezas. Seguir seus conselhos não seria ruim para o país e, particularmente, para as trabalhadoras e trabalhadores brasileiros (Puty, Francês, Carvalho, Silva da Silva e Alves da Silva, 2017,35-36).

Há controvérsias no tratamento das estimativas demográficas. Enquanto o Executivo alardeia que vivemos uma transição demográfica que exige uma mudança drástica hoje na estrutura da previdência social, a ANFIP faz um balanço diverso dos impactos de tal transição para o desempenho da previdência:

(...) o Brasil não vive nem está perto de viver qualquer crise demográfica. Em 2016, entre as faixas etárias de 16 a 23 - identificadas como sendo as mais propícias para a entrada no mercado de trabalho, nas diversas fases de escolarização - existiam 27,4 milhões de brasileiros. Na faixa oposta, de 58 a 65 anos, havia 13,9 milhões, menos da metade. Segundo o IBGE, daqui a 10 anos, essas mesmas faixas conterão 25,6 milhões e 18,1 milhões, respectivamente. Em todo esse período há mais brasileiros para entrar no mercado de trabalho do que para sair dele. A principal demanda econômica e social é, portanto, a de mais e melhores empregos para todos esses brasileiros. Somente a partir de 2037, haverá mais brasileiros saindo do que entrando no mercado de trabalho. E mesmo assim não será o caos, porque $62 \%$ da população brasileira terá entre 16 e 64 anos, teremos quase dois terços da população em idade laboral. Em 2060, último ano da estimativa do IBGE, ainda teremos $60 \%$ da população nessa faixa de idade laboral. Para se ter uma ideia, em 1980, o percentual da população com idade entre 15 e 64 anos (adotando as faixas publicadas pelo IBGE) era de $57,6 \%$, inferior ao que teremos em 2060. Isto significa, proporcionalmente, que existiam à época menos pessoas em idade para participar da produção de bens e serviços do que existirão em 2037. A proporção de idosos era menor, mas havia 38\% da população em idade não-ativa, abaixo de 15 anos" (ANFIP, 2018, 62)

Há, por outro lado, uma dimensão malthusiana nas projeções que instruem uma proposta de reforma baseada na perspectiva de uma crise inevitável do sistema de repartição simples e não consegue ocultar que, no futuro, a miséria dos rendimentos auferidos pelos beneficiários da previdência seria uma fatalidade inescapável para a preservação do sistema, com sua conversão à capitalização. Tais projeções desconsideram, em primeiro lugar, uma dimensão básica do mercado de trabalho brasileiro, que é o nível elevado de informalidade. Os dados acima, apresentados na Tabela 1, sobre a redução da participação de outros recursos da seguridade para custear a previdência entre 2005 e 2011, além das contribuições previdenciárias específicas, indicam que ainda há espaço para sustentar a previdência brasileira com políticas de reforço da formalização. Por outro lado, o anúncio da crise terminal do sistema de 
repartição não leva em conta o impacto que a elevação da produtividade do trabalho, em especial através do incremento da inovação tecnológica, pode trazer para as receitas previdenciárias, modificando os parâmetros de cálculo da razão de dependência que se elevaria com o envelhecimento da população. Uma vez que o incremento da produtividade acentua o valor criado por cada trabalhador individualmente, ele compensa a redução do número de pessoas ocupadas, favorecendo a sustentação das contribuições previdenciárias, com alteração das modalidades de sua efetivação (Gentil, Araújo, Puty, Silva, 2017; Eatwell, 2002), eventualmente diminuindo a incidência sobre a folha de pagamentos e elevando, por exemplo, a contribuição derivada do faturamento. Neste caso, garantir a vitalidade da previdência social passa pela sua articulação com políticas industriais e de apoio à inovação. Por fim, no ambiente atual brasileiro há, ainda espaço variado para o aumento da arrecadação, com a mudança na política de desonerações e isenções, mais efetividade na fiscalização à sonegação e na cobrança das dívidas, além da redução do saldo da conta única do Tesouro (Gentil, Araújo, Puty, Silva, 2017). O impacto geral seria o aumento da demanda, da atividade e das contribuições.

Se tomarmos a seguridade social como um todo, o déficit apregoado pelo Executivo é, segundo a ANFIP, resultado de artifícios para elevação de despesas e redução da arrecadação. Para a entidade, duas operações de subtração de valores são efetuadas nas receitas. A primeira é a DRU, que hoje consome $30 \%$ das receitas da seguridade, excluídas as contribuições previdenciárias. A segunda é a desconsideração de receitas diversas, como as compensações pelas desonerações e os recursos de aplicações financeiras de órgãos da seguridade. Mais controverso, a ANFIP aponta ainda o PIS-PASEP como um recurso a ser contabilizado nas receitas da seguridade, por sustentar o seguro-desemprego e fundos do BNDES (40\% do que é arrecadado) para programas de crédito a favor de empresas na geração de emprego. Nas despesas, o Executivo acrescenta os dispêndios com os regimes de servidores e militares que não são da seguridade social (ANFIP, 2018). Considerando o período que se estende de 2005 a 2017, os diferentes resultados da seguridade, nos termos da CF (conforme entendimento da ANFIP), e aquele apresentado pelo Executivo são comparados na tabela 5 .

Observa-se, pois, que o déficit da previdência social e da seguridade social apresentado como justificativa para sua reforma é, no mínimo, controverso e, no limite, uma falácia. O desempenho negativo de ambos coincide com o mergulho do país na recessão, combinado a políticas de precarização do trabalho. Por outro lado, não se pode, evidentemente, fechar os olhos aos dilemas atuariais que decorrem das mudanças demográficas em curso. A elevação do número de idosos e a redução do contingente de pessoas em idade ativa podem exigir ajustes pontuais nas contribuições e nas idades de ingresso e saída do mercado de trabalho, renovando periodicamente o pacto entre gerações que subjaz à perspectiva solidária do sistema de repartição, sem supressão de direitos ou reformas drásticas que alterem totalmente 


\begin{tabular}{|c|c|c|c|c|c|c|c|c|c|c|c|c|}
\hline \multicolumn{8}{|c|}{ 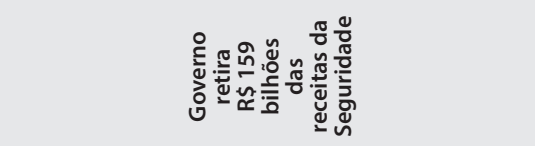 } & \multicolumn{3}{|c|}{ 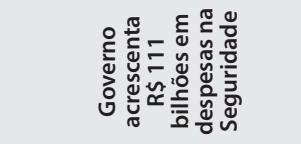 } & \multirow[b]{2}{*}{$\begin{array}{l}\text { ळ } \\
o \\
\stackrel{+}{T}\end{array}$} & \\
\hline$\hat{\bar{N}}$ & $\begin{array}{c}\stackrel{N}{m} \\
\stackrel{0}{0} \\
\stackrel{\infty}{\sim}\end{array}$ & 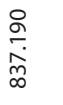 & 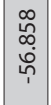 & $\begin{array}{l}\stackrel{N}{m} \\
m \\
\infty \\
\infty\end{array}$ & 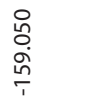 & $\begin{array}{l}\infty \\
\infty \\
\infty \\
\stackrel{m}{n} \\
\text { nd }\end{array}$ & 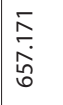 & 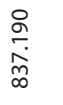 & 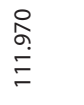 & $\frac{8}{\frac{8}{\sigma}}$ & & \\
\hline$\frac{0}{\stackrel{N}{2}}$ & $\frac{n}{\frac{n}{\sigma}}$ & 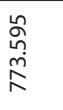 & 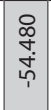 & $\frac{n}{\frac{n}{\sigma}}$ & $\begin{array}{l}8 \\
8 \\
\\
\\
1\end{array}$ & 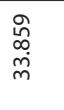 & $\begin{array}{l}m \\
m \\
m \\
\infty \\
0\end{array}$ & $\begin{array}{l}\text { nू } \\
\text { م̂n } \\
\stackrel{n}{N}\end{array}$ & 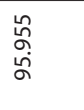 & 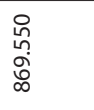 & 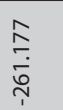 & \\
\hline$\stackrel{n}{\stackrel{n}{\infty}}$ & $\begin{array}{l}\bar{y} \\
\text { J }\end{array}$ & $\begin{array}{l}\infty \\
\stackrel{\infty}{\infty} \\
\stackrel{0}{0} \\
0 \\
0\end{array}$ & $\begin{array}{l}n \\
\hat{b} \\
\ddot{n} \\
\underline{n}\end{array}$ & $\begin{array}{l}\bar{J} \\
\text { ơ } \\
\text { gे }\end{array}$ & $\begin{array}{l}n \\
\infty \\
\infty \\
0 \\
0 \\
1\end{array}$ & $\begin{array}{l}\hat{n} \\
\frac{n}{m}\end{array}$ & 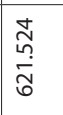 & $\begin{array}{l}\infty \\
\infty \\
\stackrel{0}{\infty} \\
\infty \\
0\end{array}$ & $\frac{\bar{g}}{\stackrel{E}{E}}$ & 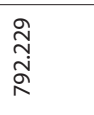 & 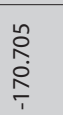 & \\
\hline$\frac{\pi}{\grave{N}}$ & 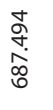 & $\begin{array}{l}\sigma \\
\sigma \\
\check{\widehat{\sigma}}\end{array}$ & 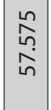 & $\begin{array}{l}\stackrel{g}{\sigma} \\
\stackrel{\infty}{\infty} \\
\stackrel{\infty}{0}\end{array}$ & $\underset{\substack{\stackrel{\infty}{\sim} \\
\stackrel{\sim}{\tau}}}{\sim}$ & $\begin{array}{l}0 \\
\stackrel{0}{\text { Na }}\end{array}$ & 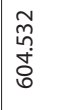 & 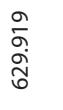 & $\begin{array}{l}\bar{\sigma} \\
\infty \\
\stackrel{0}{0}\end{array}$ & 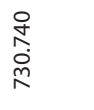 & 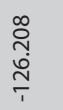 & \\
\hline$\frac{m}{i}$ & $\frac{\bar{m}}{\stackrel{\sim}{-}}$ & i̊ & $\begin{array}{l}\delta \\
\infty \\
\infty \\
\infty \\
\kappa\end{array}$ & \begin{tabular}{l}
$\bar{m}$ \\
\multirow{i}{j}{} \\
\end{tabular} & $\begin{array}{l}\bar{\Sigma} \\
\infty \\
\dot{0} \\
1\end{array}$ & 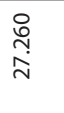 & $\begin{array}{l}\bar{\infty} \\
\infty \\
\infty \\
i \\
i n\end{array}$ & 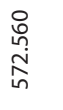 & $\begin{array}{l}n \\
\hat{\alpha} \\
\text { ڤn } \\
\alpha\end{array}$ & $\begin{array}{l}\tilde{n} \\
\tilde{0} \\
\stackrel{0}{0} \\
0\end{array}$ & $\begin{array}{l}\stackrel{+}{\kappa} \\
\text { ஸ̆ } \\
\hat{i}\end{array}$ & \\
\hline$\frac{0}{2}$ & 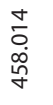 & $\begin{array}{l}\text { पे } \\
\text { +े } \\
\text { ơ }\end{array}$ & 品 & $\begin{array}{l}\nabla \\
\sigma \\
\infty \\
b^{\circ} \\
y\end{array}$ & \begin{tabular}{l}
$\stackrel{0}{\circ}$ \\
$\stackrel{2}{+}$ \\
\multirow{1}{*}{}
\end{tabular} & 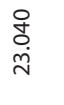 & $\begin{array}{l}n \\
o \\
0 \\
o \\
+\end{array}$ & $\begin{array}{l}\text { ষ্ণ } \\
\text { ণें } \\
\text { ơ }\end{array}$ & 兽 & 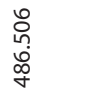 & 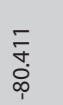 & \\
\hline ठ્సે & $\begin{array}{l}\text { J } \\
\infty \\
\vdots \\
\bar{m}\end{array}$ & $\begin{array}{l}\stackrel{n}{N} \\
\stackrel{n}{n} \\
\end{array}$ & $\begin{array}{c}\frac{a}{m} \\
\dot{m} \\
m\end{array}$ & $\begin{array}{l}\text { J } \\
\infty \\
\dot{⿰} \\
\dot{m}\end{array}$ & $\begin{array}{l}n \\
\\
\infty \\
\tilde{n} \\
\varphi \\
\end{array}$ & $\begin{array}{l}\text { 오 } \\
\stackrel{n}{\text { Dे }}\end{array}$ & $\begin{array}{l}\stackrel{2}{2} \\
m \\
\infty \\
\infty \\
m\end{array}$ & 華 & $\begin{array}{l}\text { N్} \\
\hat{n} \\
\sigma \\
0\end{array}$ & 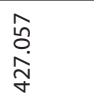 & $\begin{array}{l}\underset{m}{\stackrel{n}{n}} \\
\stackrel{\infty}{i}\end{array}$ & \\
\hline ठ̊ & 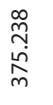 & 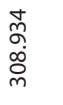 & 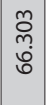 & 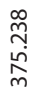 & $\begin{array}{l}\dot{0} \\
\infty \\
\\
\hat{\varphi}\end{array}$ & $\begin{array}{l}\hat{m} \\
\stackrel{\infty}{\infty} \\
\stackrel{-}{=}\end{array}$ & స్̃ & $\begin{array}{l}\stackrel{+}{m} \\
o \\
\infty \\
\infty\end{array}$ & 岇 & $\begin{array}{l}\frac{1}{\infty} \\
\frac{0}{m} \\
m\end{array}$ & 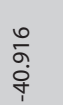 & \\
\hline ஜ̊̊ి & $\begin{array}{l}\frac{\infty}{m} \\
\stackrel{\infty}{\infty} \\
\stackrel{\infty}{\infty}\end{array}$ & 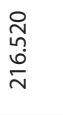 & 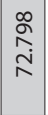 & $\begin{array}{l}\stackrel{\infty}{m} \\
\stackrel{\infty}{\infty} \\
\sim\end{array}$ & 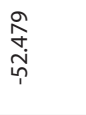 & $\begin{array}{l}\stackrel{\mathscr{\vartheta}}{f} \\
\stackrel{=}{=}\end{array}$ & 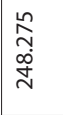 & 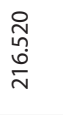 & 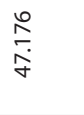 & 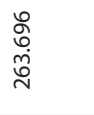 & $\begin{array}{l}\bar{y} \\
\stackrel{y}{n} \\
\end{array}$ & \\
\hline & 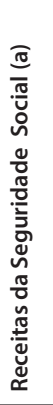 & 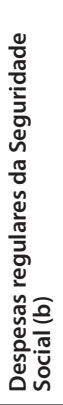 & \multirow{2}{*}{ 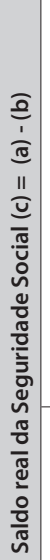 } & 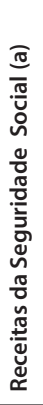 & 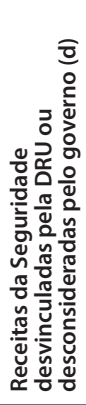 & 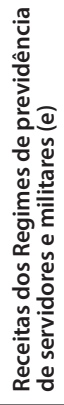 & 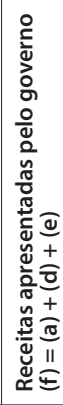 & 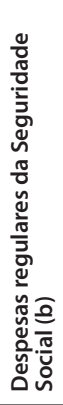 & 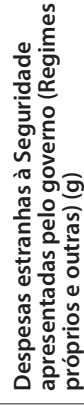 & 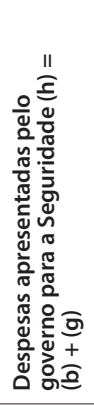 & \multirow{2}{*}{ 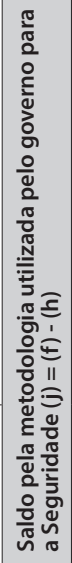 } & 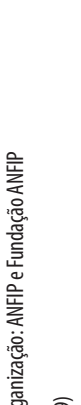 \\
\hline & \multicolumn{2}{|c|}{ 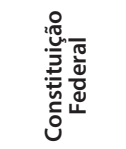 } & & \multicolumn{4}{|c|}{ 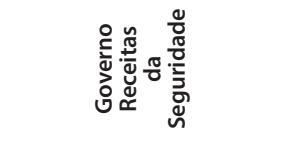 } & \multicolumn{3}{|c|}{ 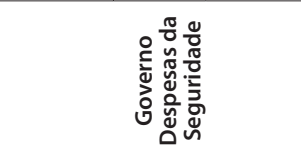 } & & 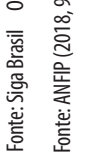 \\
\hline
\end{tabular}


o curso de vida das pessoas (Delgado, 2001). Aliás, reformas têm sido efetuadas desde a década de 1990 e deverão ser continuar a acontecer, sem mudanças bruscas, de forma pactuada. Por seu turno, medidas específicas para os regimes próprios devem ser objeto de debates, mas considerando as particularidades de cada um. No caso dos servidores civis, a reforma no sentido da convergência com o regime geral já se efetuou, com acréscimos de exigências que o segundo não tem e a criação de um regime complementar de capitalização com contribuição definida. O "déficit" decorre do estoque de aposentados constituído antes dessas mudanças e deveria, pois, ser tratado como outro tipo de despesa, consoante com as disposições legais anteriores. No caso dos militares, o debate deveria partir de considerações sobre a natureza de sua carreira. Em boa parte dos países os militares não contribuem porque, conceitualmente, sua reforma não significa aposentadoria (por exemplo, em situação de guerra podem ser convocados). Evitar este debate, todavia, apresentando uma proposta de reforma acompanhada de mudanças na carreira que praticamente anulam a contribuição a ser cobrada é mais um truque, uma prestidigitação, cujo objetivo é fingir que se combate privilégios para fazer o que a "Nova Previdência" efetivamente quer: um ataque aos direitos dos trabalhadores e a liquidação de nosso ainda precário Estado de BemEstar Social.

\section{A NOVA ILUSÃO AMERICANA}

A "reforma da previdência" proposta no governo Temer previa um tempo de contribuição para a aposentadoria de tal extensão que, nas condições brasileiras, desestimularia muitos jovens que ingressam no mercado de trabalho a contribuir para a previdência pública. A "reforma trabalhista", por sua vez, alargando as modalidades de contratação sem carteira assinada, está intensificando o declínio da já baixa formalização do mercado de trabalho e conseqüentemente da base de arrecadação da previdência social. Além de parte de um ajuste fiscal seletivo, que penaliza fundamentalmente os pobres, a reforma de Temer mirava, mas não tornava explícito, o incremento da previdência privada. A reforma de Bolsonaro e Guedes pelo menos não escondeu esse propósito, pois além de tornar mais draconianas as condições para a aposentadoria, se comparada à reforma de Temer, propõe a substituição do sistema de repartição simples pelo de capitalização.

Há interesses personalíssimos nesta empreitada que seriam desvendados se houvesse disposição de perscrutar a trajetória de seus propositores. Há, do mesmo modo, a vontade dos bancos, que hoje ocupam, junto com interesses externos, o centro do bloco no poder que domina o Estado brasileiro, além de terem influência crucial sobre a mídia tradicional. Mas há também, concedamos alguma boa fé naqueles que entendem ser a criação do sistema de capitalização uma medida importante para dinamizar o mercado de capitais no Brasil, estimulando o investimento e a expansão do emprego. 
A criação do sistema de capitalização não resolve o problema do déficit público, como percebemos na situação chilena, pois o Estado tem que arcar com o custeio das aposentadorias do regime substituído, na medida em que os antigos contribuintes do sistema de repartição migram para o novo modelo (Mesa-Lago, 2003). No formato da contribuição definida, o regime de capitalização torna incerto o rendimento de seus beneficiários no futuro, já que fica à mercê das flutuações do mercado financeiro e da gestão dos fundos. O cenário de precarização das aposentadorias dos chilenos é uma demonstração cruel de como tal incerteza não tende a se revelar como uma surpresa positiva. Por fim, numa perspectiva de longo prazo, o sistema de capitalização, em seu conjunto, tende a convergir com o modelo de repartição simples, à medida que a base de contribuição se reduzir, após várias gerações, em meio ao processo de transição demográfica (Schwarzer, 1999). Quando há mais pessoas a sacar do que a contribuir, os recursos a aplicar também se reduzem.

Os fundos de pensão de contribuição definida e os de previdência aberta tendem a dispor de perspectiva de curto prazo em suas aplicações, reagindo ao movimento momentâneo do mercado, talvez porque no primeiro caso, não têm muitas preocupações com o que deverão entregar aos beneficiários na hora da aposentadoria; ou por serem os fundos de previdência aberta, no limite, equivalentes a outros fundos de investimento (De Conti, 2016). Considerado o cenário de financeirização que prevalece na ordem capitalista contemporânea, sua inclinação é para investimentos com reduzido impacto no sistema produtivo. Os fundos de pensão fechados, de benefício definido tendem a dispor de relativa inclinação para aplicações de longo prazo (De Conti, 2016), se não estabelecerem um improvável cabo de guerra com seus clientes sobre o valor das contribuições. Ainda assim, o espaço para inversões que envolvam risco e incerteza é reduzido. Risco e incerteza são elementos centrais de investimentos inovadores de maturação longa, exigindo formas de financiamento mais pacientes, em geral ligados aos bancos de investimento, notadamente públicos.

Estudo recente da consultoria Accenture (2018) apresenta dados interessantes para a análise do papel mercado de capitais e dos fundos de pensão na promoção do desenvolvimento e no incremento da inovação tecnológica, crucial para o alcance de patamares mais elevados de desenvolvimento e para a busca de soluções no sentido da preservação do direito à aposentadoria com as mudanças no mercado de trabalho, tal como apontado na seção anterior deste artigo. 
Figura 1 - Definição de um mercado de capitais desenvolvido

\begin{tabular}{|c|c|c|c|}
\hline & $\begin{array}{l}\text { Valor dos títulos } \\
\text { privados emitidos } \\
\text { Dados em \% do PIB }\end{array}$ & $\begin{array}{l}\text { Capitalização } \\
\text { de mercado } \\
\text { Dados em \% do PIB }\end{array}$ & $\begin{array}{l}\text { Quantidade de } \\
\text { empresas listadas } \\
1.000 \text { habitantes }\end{array}$ \\
\hline ô 1. Islândia & 69,8 & 70,3 & 18,1 \\
\hline$\sum_{2}^{0}$ 2. Austrália & 56,5 & 106,0 & 8,2 \\
\hline 总 3. Hong Kong & 16,5 & 687,4 & 17,0 \\
\hline ปั 4. Malásia & 51,4 & 132,3 & 3,4 \\
\hline$\stackrel{\frac{\pi}{\pi}}{\frac{\pi}{\varepsilon}}$ 5. Canadá & 30,2 & 111,4 & 9,6 \\
\hline 6. Singapura & 17,2 & 193,2 & 10,0 \\
\hline 잉 7. EUA & 106,1 & 118,8 & 1,7 \\
\hline 용 8. Espanha & 42,0 & 82,7 & 7,4 \\
\hline 胥 9. Coréia do Sul & 62,3 & 72,5 & 3,5 \\
\hline$\sum$ 10. Dinamarca & 135,0 & 53,1 & 3,6 \\
\hline Média & 58,7 & 162,8 & 8,2 \\
\hline$\sum_{\sum}^{\ll} 16$. Reino Unido & 15,7 & 117,0 & 4,0 \\
\hline 作 17. Chile & 38,7 & 106,1 & 1,3 \\
\hline 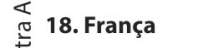 & 45,1 & 76,9 & 1,2 \\
\hline 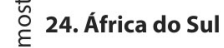 & 17,1 & 204,8 & 0,7 \\
\hline 28. Alemanha & 38,2 & 43,9 & 0,9 \\
\hline 38. Peru & 10,0 & 38,6 & 0,7 \\
\hline 50. Colômbia & 0,4 & 38,4 & | 0,2 \\
\hline Média & 23,3 & 89,4 & 1,3 \\
\hline $\bar{\Phi}$ 36. China & 27,9 & 46,6 & 0,1 \\
\hline 裵 37. Rússia & & 5,31 & | 0,3 \\
\hline ¿્ 44. México & 13,2 & 29,7 & $\mid 0,1$ \\
\hline$\frac{\pi}{2}$ 46. Turquia & $\mid 0,9$ & 29,7 & $\mid 0,4$ \\
\hline$\approx$ ॠ 48. Argentina & 6,0 & 17,2 & 0,3 \\
\hline Média & 10,7 & 35,2 & 0,2 \\
\hline 35. Brasil & 22,1 & 49,0 & $\mid 0,2$ \\
\hline
\end{tabular}

Fonte: ACCENTURE (2018) 
Figura 2 - Comparações Internacionais

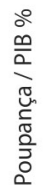

ơ

16. Reino Unido

17. Chile

18. França

24. África do Sul

28. Alemanha

38. Peru

50. Colômbia

Média

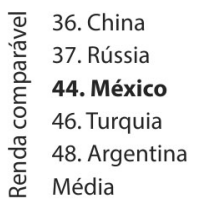

35. Brasil
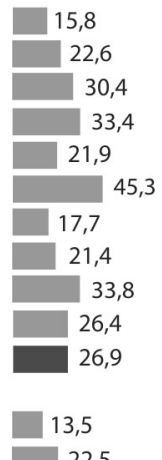

\section{1,4}

16,3

\section{5,1}

20,6

17,8

19,5

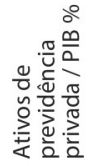

124,7

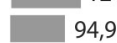

124,7
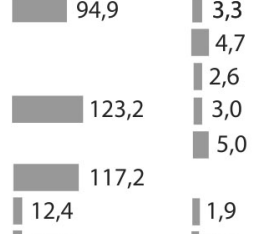

13,8
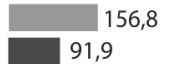

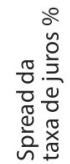

1,9

1,7

3,2
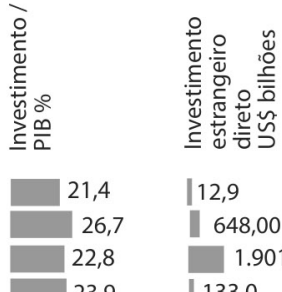

1,4

| 12,9

26,7

648,00

$1.901,00$

23,9 | 133,0

23,0

$1.045,0$

$1.158,0$

26,2
20,7

$4.084,0$

25,

31,1

21,1

772,0

| 194,0

| 145,9

\begin{tabular}{l}
24,2 \\
\hline
\end{tabular}

\begin{tabular}{|c|c|}
\hline 77,3 & \\
\hline 59,8 & 3,7 \\
\hline 7,3 & 4,0 \\
\hline 81,5 & 3,3 \\
\hline $\mid 5,0$ & 6,7 \\
\hline 16,0 & 18,0 \\
\hline 13,7 & 7,2 \\
\hline 37,2 & 7,3 \\
\hline
\end{tabular}

\begin{tabular}{|c|}
\hline 16,8 \\
\hline 22,9 \\
22,5 \\
19,5 \\
19,8 \\
21,8 \\
22,2 \\
20,8 \\
\hline
\end{tabular}

$2.0027,0$

209,0

843,0

| 139,0

$1.455,0$

| 97,0

| 178,0

706,9

\begin{tabular}{|c|l|c}
\hline 47,9 & $\mid 0,7$ & 3,1 \\
28,4 & $\mid 2,9$ & 6,4 \\
22,4 & 10,8 & 4,3 \\
22,7 & $\mid 2,5$ & \\
18,0 & 11,4 & 5,7 \\
27,9 & $\mid 5,7$ & 4,9 \\
& & \\
16,2 & 15,9 & \\
\hline
\end{tabular}

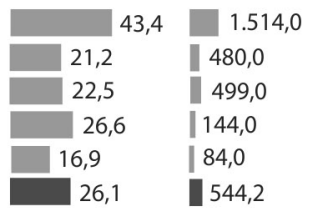

19,2

829,00 
Entre os países apontados como os que dispõem de "mercado de capitais" desenvolvido, a Coréia do Sul apresenta a maior relação investimento/PIB, mas a participação dos fundos de pensão privados no PIB é pouco relevante, menor mesmo que a do Brasil. Já a China não aparece na relação dos países com mercado de capitais desenvolvido, conquanto seu peso seja significativo, considerando os indicadores valor dos títulos privados emitidos/PIB e capitalização de mercado/PIB. A participação dos fundos de pensão privados no país, todavia, é virtualmente inexistente, como proporção do PIB, ao passo que entre todos os casos listados, é o que ostenta a maior relação investimento/PIB. Já o Chile, modelo da proposta de reforma de Bolsonaro e Guedes, apresenta números maiores que os do Brasil nos indicadores do mercado de capitais considerados nas figuras acima, com uma participação de quase $60 \%$ dos ativos privados de previdência em relação ao PIB (15,9\% no Brasil), mas a relação investimento/PIB (22,9\%), embora expressiva, não chega a estabelecer uma distância dilatada em relação ao Brasil (19,2\%), especialmente quando se considera que tais valores compreendem a média de 2001 a 2017, período em que, na partida e na chegada da série, o país viveu momentos de baixo desempenho econômico.

A literatura sobre as variedades de capitalismo aponta os EUA e a Alemanha como países representativos de tipos polares de ordenamento da economia capitalista, respectivamente o tipo liberal e o tipo coordenado, considerando variáveis como a governança e as finanças corporativas, as relações industriais, a autoridade no interior da firma, as relações entre fornecedores e clientes, além dos padrões e dos instrumentos de capacitação da força de trabalho (Hall \& Soskice, 2001). Os eixos de estruturação dos dois tipos - que são, de todo modo, economias de mercado capitalistas -seriam, no liberal, o mercado e o preço, e no coordenado, a articulação entre os atores, a pactuação permanente. Nas finanças corporativas, a distinção básica seria o predomínio do mercado de capitais, no tipo liberal, e o investimento dos bancos, no tipo coordenado. Daí as diferenças evidenciadas na Figura 2 acima, gritantes em relação ao mercado de capitais, com os EUA apresentando indicadores exponencialmente mais elevados que os da Alemanha (os maiores da relação apresentada, se tomarmos apenas países com população e territórios médios ou grandes), mas com taxas de investimento próximas (respectivamente, $20,7 \%$ e $19,8 \%$ do PIB) e desempenho similar nas inversões em inovação tecnológica (2,7\% e 2,6\% em relação ao PIB). Já a Coréia do Sul, entre os casos destacados aqui, é o que mais investe em P\&D, 3,2\% do PIB; a China investe 1,5\%; o Brasil 1,1\% e o Chile miseráveis 0,4\% ${ }^{7}$.

Quando Jair Bolsonaro prestou continência à bandeira dos EUA, expressava uma reverência que vai além da submissão à liderança daquele país no campo das disputas geopolíticas. Com seu modo tosco e espalhafatoso, replicava um sentimento muito difundido no Brasil, a Ilusão Americana de que falava Eduardo Prado em 1893, que tende a mirar os EUA como o projeto de país a ser replicado no país (Prado, 2003). Mas se Eduardo Prado, um monarquista, lamentava a instalação da República, a Nova Ilusão Americana mira os EUA a partir de uma ficção construída na alma vira lata de 
quem dela é portador. Se o mercado de capitais e os fundos de pensão têm papel significativo para o investimento produtivo nos EUA, seu desenvolvimento econômico e tecnológico depende significativamente do poder de compra do Estado, em especial na área da defesa, que se irradia, inclusive através de disposições legais, por todo o tecido produtivo, além das enormes inversões públicas em pesquisa, que municiam as grandes corporações norte-americanas de um insumo que não poderiam desenvolver por conta própria, dada a incerteza quanto aos resultados que envolve as atividades de P\&D (Delgado, Condé, Esther, Salles, 2010). Além disso, como em todos os países desenvolvidos que dispõem de população e territórios médio ou extenso, a pujança da economia dos EUA associou-se, também, à presença de grandes empresas nacionais, apoiadas pelo Estado em seu processo de crescimento e projeção para o exterior.

\section{Gráfico 1}

Ativos das entidades fechadas de previdência complementar (2004-2014)

(Carteira consolidada, por tipo de aplicação em \% do total)

6 A - Ativos das entidades fechadas de previdência complementar (2004-2009)

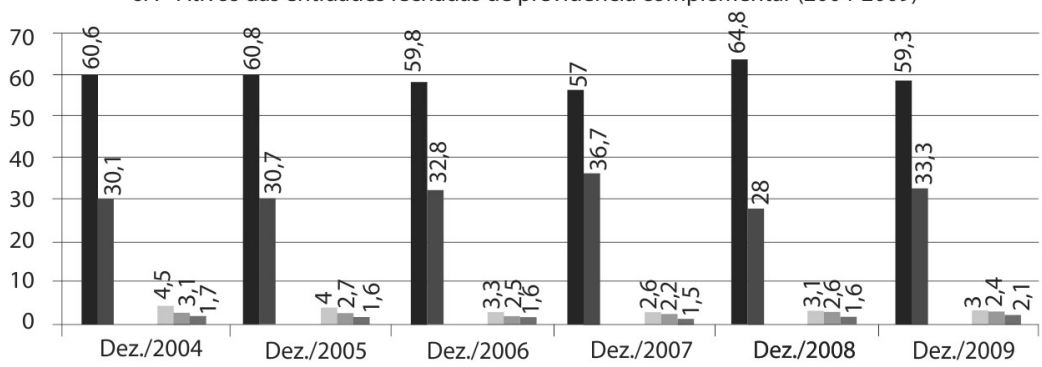

Renda fixa Renda variável

- Imóveis घ Operações com participantes @ Outros

19a Investimentos estruturados $\square$ Investimentos no exterior

6A - Ativos das entidades fechadas de previdência complementar (2004-2009)

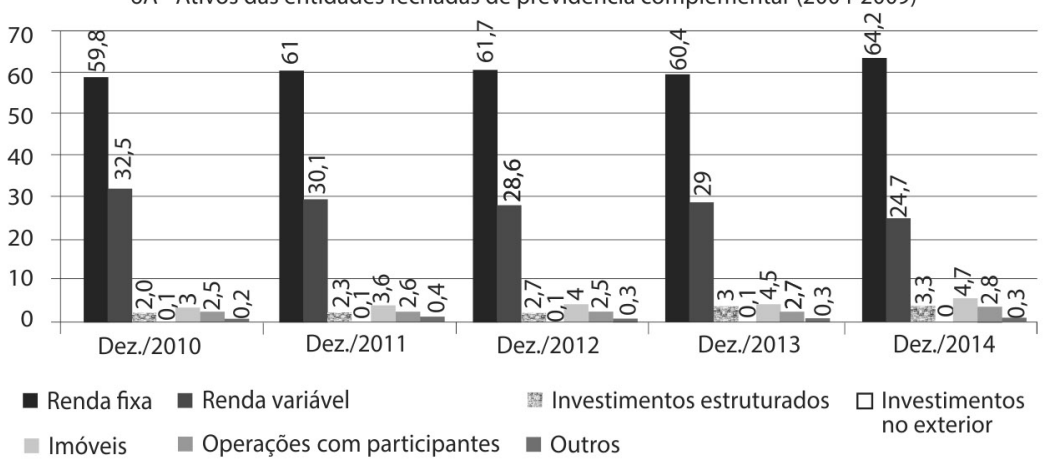

Fonte: De Conti, 2016, 360. 
Nos países que chegaram tarde, como a Alemanha e o Japão, a constituição de bancos de investimento foi elemento central para o sucesso das políticas de emparelhamento e, entre os países que adotaram estratégias desenvolvimentistas após a Segunda Guerra Mundial, a presença de bancos públicos foi decisiva para a criação de condições seguras de financiamento para o investimento produtivo, imune às flutuações do mercado de capitais (Amsden 2009; Delgado, 2015). Esse, por sua vez, nos casos da China e da Coréia do Sul, se desenvolveu em etapas posteriores do arranque industrial, sem substituir a centralidade dos bancos de investimento, em boa medida associado à abertura do capital de empresas nacionais vigorosas, não de seu enfraquecimento e da especulação financeira.

Uma pequena amostra das inversões dos fundos de pensão fechados no Brasil indica o peso de suas aplicações em renda fixa e a participação reduzida das inversões em outros ativos, mais associados ao investimento produtivo.

Por fim, a financeirização da economia brasileira parece inclinar mesmo empresas não financeiras a conferir destaque a aplicações distintas de sua atividade principal, dada a rentabilidade obtida em investimentos no sistema financeiro. Num levantamento efetuado por Finello, Corrêa, Lemos e Feijó, o lucro operacional das empresas não financeiras, de 1996 a 2014, só foi mais elevado que os lucros não operacionais (distintos dos obtidos em sua atividade principal) entre 2004 e 2007 e em 2011.

\section{Gráfico 2}

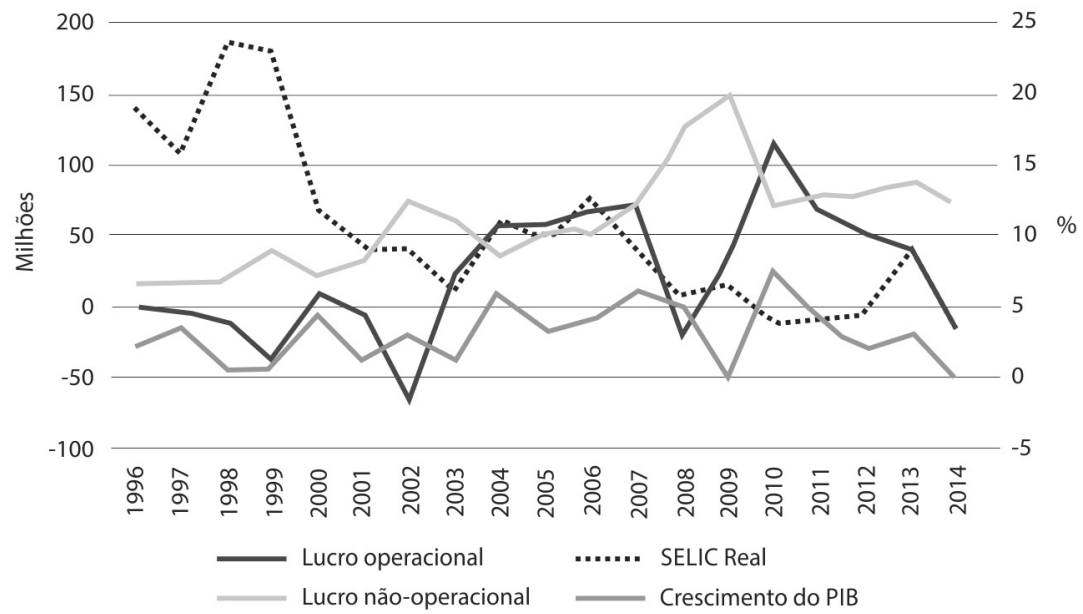

1 A taxa Selic real anual foi calculada através da média geométrica das taxas reais mensais acumuladas ao ano. 0 índice de inflação utilizado foi o IPCA. 20 lucro operacional foi calculado através da subtração da despesa não operacional total da receita não operacional total. 30 lucro não operacional foi calculado através da subtração da despesa não operacional total da receita não operacional total. Fonte: Pesquisa Industrial Anual (PIA) - IBGE, BACEN, Bacen Brasil (Selic), Carta Conjuntura n. 31 Ipea (PIB). Elaboração própria 
No primeiro período, houve forte expansão da economia brasileira, conjugado à presença de políticas industriais ativas; já em 2011, assiste-se ao declínio da taxa Selic, combinado a ações dos bancos públicos para pressionar o setor financeiro privado a reduzir o spread bancário.

Com a presença de taxas de juros elevadas, utilizadas não só para as políticas de combate à inflação, mas também para a atração de capitais externos na busca de equilíbrio do balanço de pagamentos, dada a concentração existente no sistema bancário brasileiro, é pouco provável que a ampliação da previdência privada e a universalização do sistema de capitalização venham a se converter num condão que, magicamente, eleve o investimento produtivo. É possível que se tornem mais uma peça da engrenagem que hoje sustenta a financeirização da economia do país, ao custo da degradação das atividades da economia real, da redução da demanda (que, hoje, com o sistema de repartição, impulsiona a economia de inúmeros municípios brasileiros), da acentuação da pobreza e da condenação dos idosos à miséria e a ao desalento.

\section{TEMPO LIVRE, CIDADANIA E DESENVOLVIMENTO}

Nos direitos sociais (Título II, Capítulo II) elencados na Constituição de 1988, a aposentadoria está incluída no inciso XXIV do artigo 70, que discorre sobre os "direitos dos trabalhadores urbanos e rurais, além de outros que visem à melhoria de sua condição social". O mesmo artigo, no inciso XXVII, prevê que os trabalhadores devem dispor de "proteção em face da automação, na forma da lei".

No início da trajetória do pacto social que instituiu os modernos estados de BemEstar social, a regulamentação da jornada de trabalho foi a primeira medida a restringir a operação livre do mercado, de modo a impedir que produtores, dissociados dos meios de produção por conta do advento da máquina a vapor e da indústria moderna, tivessem suas forças e seu tempo livre exauridos pelo trabalho contínuo no interior das fábricas. À frente, os sistemas de aposentadoria e pensões forjaram a segunda geração das políticas de proteção, dirigidas agora aos idosos, os mais atingidos por acidentes de trabalho e pelo desemprego. Elevar o tempo livre dos trabalhadores na ativa e garantir aos idosos a fruição de tempo livre em condições dignas, recebendo uma remuneração que não obteriam mais na atividade laboral, foram, por assim dizer, os parâmetros iniciais de um acordo que, ao assegurar condições mínimas de igualdade, ampliavam o espaço de liberdade das pessoas, por disporem de tempo livre para a expressão de suas subjetividades num ambiente de convivência comum, de fraternidade, por compartilharem um mesmo status, a cidadania, cujo lócus tem sido, até aqui, o Estado Nacional ${ }^{8}$. Esses foram os passos iniciais na superação daquilo que Polanyi (1980) definiu como o moinho satânico do livre mercado.

Vivemos num tempo em que as mudanças tecnológicas favorecem a elevação da riqueza geral, mas com alterações na estrutura produtiva que tendem a reduzir o 
número de postos de trabalho associados a diversas profissões e, no limite, as exigências de contratação no conjunto do sistema econômico. Ao mesmo tempo, mudanças demográficas sugerem que os sistemas de aposentadoria e pensão baseados na solidariedade entre as gerações precisam de ajustes, dados os dilemas atuariais que decorrem do crescimento da participação dos idosos no conjunto da população e da redução progressiva do número de pessoas que ingressam no mercado de trabalho. Alguns países têm lidado com esses desafios através de expedientes que reinventam as respostas inaugurais da reação ao mercado totalmente desregulado, com a redução da jornada de trabalho e a busca de formas novas de financiamento da previdência social.

Como o Brasil deve lidar com esses dilemas? Regredir a formatos que permitam a livre operação do moinho satânico, instituindo relações de trabalho que tornam frágil a proteção aos trabalhadores para usufruto de seu tempo livre? Definir um regime de aposentadoria que torna incerta sua existência como um direito? Não há a mínima possibilidade de tais arranjos produzirem resultados que assegurem "os direitos dos trabalhadores urbanos e rurais, além de outros que visem à melhoria de sua condição social" e sua "proteção em face da automação, na forma da lei". A elevação da riqueza geral proporcionada pelas mudanças tecnológicas em curso, num ambiente regulatório definido pela "reforma trabalhista" e pela "nova previdência", vai se associar à criação de uma multidão de pessoas trabalhando muito, de forma precária, em serviços de baixa qualidade, quando não desempregadas.

O Brasil vive uma encruzilhada. Ao contrário de uma crença muito difundida, trabalho precário e inovação tecnológica são forças que operam em direções opostas. Na Coréia do Sul, no Japão, na Alemanha, os contratos de longa duração favorecem a identificação dos trabalhadores com as empresas, o aprendizado contínuo, o desenvolvimento da qualidade dos produtos e o envolvimento em processo de inovação. Nos EUA, em que é mais elevado o turnover, os departamentos de P\&D das grandes corporações são separados das plantas das fábricas e neles os contratos de trabalho são generosos, como forma de proteger o segredo industrial que é uma dimensão central das atividades de inovação tecnológica no país ${ }^{9}$. Se a legislação trabalhista constituída a partir de Vargas precisa ser continuamente atualizada (como, aliás, tem sido desde sua criação), reduzindo, inclusive, sua complexidade burocrática, não é a completa precarização das relações de trabalho que vai constituir no país um ambiente favorável à inovação no âmbito das empresas.

A criação do sistema de capitalização, como se viu na seção anterior, tem fraca relação com a elevação do investimento, favorece inversões de curto prazo e afeta negativamente a demanda, possivelmente provocando efeitos opostos aos esperados por seus propositores para a elevação do investimento e do emprego. Pode se considerar uma opção válida para a constituição de fundos de previdência complementar, de caráter público ou privado, mas como base do regime geral o sistema de capitalização esvazia a aposentadoria como um direito e não é capaz de 
gerar recursos para investimentos pacientes em projetos de maturação mais longa, capazes de ampliar o peso das atividades intensivas em tecnologia na estrutura econômica do país. Ainda que aparentemente desconexas, a criação do sistema de capitalização e os ataques ao BNDES, e o seu enfraquecimento, constituem um arranjo, sustentado pela Nova Ilusão Americana, cujo desfecho será a elevação da distância tecnológica entre o Brasil e as nações capitalistas centrais, ainda mais porque associadas à fragilização e/ou a desnacionalização das poucas empresas efetivamente brasileiras de porte global e disposição inovadora. A rigor, não há caso algum, entre os países de população e territórios médios ou extensos, em que a combinação de desenvolvimento tecnológico e bem-estar social tenha ocorrido sem a presença de grandes empresas nacionais inovadoras. No Brasil, do jeito que as coisas vão, forjase uma nova jabuticaba|: um país de extensão continental em que a maior parte das atividades intensivas em tecnologia estão, cada vez mais, sob controle externo. Se isso vai alterar o padrão até aqui verificado entre as multinacionais, que concentram as atividades de P\&D mais importantes em seus países-sede, é apenas uma esperança, sem antecedentes de relevo que permitam ao país abdicar de um projeto nacional de desenvolvimento soberano.

Enfim, se miramos enfrentar as dificuldades atuariais da previdência social e garantir a aposentadoria como um direito, o caminho proposto na "Nova Previdência" é um mergulho no abismo. A repactuação do acordo entre gerações nos sistemas de aposentadoria e pensões baseados no modelo de repartição simples exige acertos permanentes nas regras de ingresso e saída do mercado de trabalho e criatividade na definição da estrutura de contribuições. Além disso, deve estar conectada a um projeto de desenvolvimento que assegure ao país capacidade de inovar para superar sua condição semiperiférica na economia global e para a elevação da riqueza geral. Relações de trabalho que, em formatos diversos, elevem o espaço de liberdade das pessoas (a rigor, seu tempo livre), bem como seu comprometimento com o empenho inovador das empresas (impossível no âmbito de arranjos que acentuam a incerteza na relação de emprego) e a preservação e o aperfeiçoamento da seguridade social são condições para o alcance de tal intento,e para que seus resultados sejam franqueados a todos os brasileiros. 


\begin{abstract}
Notas
1 Esse artigo é uma versão de uma reflexão publicada no site da Universidad Federal de Juiz de Fora, UFJF Notícias, em maio de 2019.

2 Ver, por exemplo, o artigo de um colaborador da Infomoney, Ghani (2019)

${ }^{3}$ Desde a Lei 9630/98 o regime dos servidores federais passou a dispor efetivamente de caráter contributivo, já definido em disposições anteriores. Em 2004, a EC 41/2003 autorizou a contribuição de servidores inativos e pensionistas e, em 2012, a Lei 12.618/12 estabeleceu que, para os novos servidores, o teto das aposentadorias seria o mesmo do regime geral (Fazio, 2018). Já os militares, também considerados na CF na Organização do Estado (Título III, Capitulo VII, Seção III), mesmo inativos são considerados parte do efetivo e recebem salário, não (em tese)aposentadorias, contribuindo com 7,5\% para pensões e, opcionalmente, 1,5\% para pensão de filhas não casadas.
\end{abstract}

${ }^{4} \mathrm{G} 1(2019)$

${ }^{5}$ A recorrência e magnitude de tais erros levam Carvalho, Silva, Francês, Puty, Gentil e Silva (2017) a sugerirem a inclusão de cálculos de dispersão nas projeções relativas aos sistemas previdenciários, incluindo elementos como desvio padrão e intervalos de confiança, de modo a mitigar o impacto de decisões tomadas no presente, a partir de estimativas frágeis, mas que afetam as pessoas no futuro.

${ }^{6}$ Observam Puty e Gentil na publicação em que está incluído o estudo considerado acima: "... mais especificamente, o IBGE prevê que a proporção de idosos na população total crescerá de 12,59\% em 2015, para 35,15\% em 2060. Porém, quando analisamos isoladamente a variável população de idosos, a taxa de crescimento anual desse segmento cresce a taxas decrescentes (os acréscimos são cada vez menores ao longo do tempo). Essa informação é desconhecida do público" (Puty e Gentil, 2017, 19)

${ }^{7}$ Em estudo que fizemos sobre a política industrial de China, Índia e Brasil, com dados da Unesco, a China já havia alcançado 1,84\% do PIB no investimento em inovação em 2011. No Plano Nacional de Longo Prazo para Ciência e Tecnologia (2006-2020) previa-se o alcance de 2,5\% do PIB em investimento em inovação em 2020 (Delgado, 2015). Recentemente, o governo chinês divulgou que tal percentual já alcançara 2,1\% do PIB em 2016 (Portuguese.people.cn, 2017). Apesar das controvérsias que envolvem as estatísticas do país, a publicação da Accenture, por considerar a média entre 2001 e 2017, pode estar subestimando o desempenho da China.

${ }^{8}$ É impossível resenhar aqui a imensa literatura sobre esse processo. Para um apanhado ligeiro, ver Delgado (2001). A noção clássica de cidadania como um status compartilhado é de Marshall (1967). A conexão com a constituição Estado Nacional tem sua formulação mais significativa em Bendix (1996). Num ensaio escrito há três anos, sugerimos sua articulação com a ideia de desenvolvimento (Delgado, 2016)

${ }^{9}$ Ademais, mesmo para o conjunto das relações de trabalho, a ideia de nos EUA elas são fundamentalmente desreguladas é mais um componente da Nova llusão Americana, como nos revela Cássio Casagrande (2017)

\title{
Referências
}

ACCENTURE Impactos Socioeconômicos do fortalecimento do mercado de capitais no Brasil - Relatório Final. Accenture, 2018. Disponível em: https://bit.ly/2YHIN. Acesso em 26 abr. 2019.

AMSDEN, Alice. A Ascensão do "Resto" - o desafio ao ocidente de economias com industrialização tardia. São Paulo: Editora da UNESP. 2009.

ANFIP. Análise da Seguridade Social em 2017. Brasília: ANFIP, 2018.

BENDIX, R. Construção Nacional e Cidadania. São Paulo: EDUSP, 1996

CARVALHO, Solon, SILVA, Carlos, FRANCÊS, Carlos, PUTY, Cláudio, GENTIL, Denise, SILVA, Marcelino. A necessidade do cálculo de dispersão, para projeções sobre o comportamento de sistemas previdenciários. ? In: Carlos Alberto Puty e a Denise Lobato Gentil. A Previdência Social em 2060: As inconsistências do modelo de projeção atuarial do governo brasileiro. Brasília: ANFIP/ DIEESE; Plataforma Política Social, 2017.

CASAGRANDE, Cássio. A Reforma Trabalhista e o'sonho americano' - Uma grande ignorância sobre o direito e o sistema de justiça nos EUA. In: Jota. Disponível em https://bit.ly/2ZZikNC.

Acesso em 26 abr. 2019. 
DE CONTI, B. M. “Os fundos brasileiros de previdência complementar: segmentações analíticas e estudos preliminares sobre a alocação de seus recursos". In: Claudio Hamilton Matos dos Santos. (Org.). Características estruturais do sistema financeiro brasileiro: um registro da reflexão do lpea no biênio 20142015. Brasília: IPEA, 2016, v. 1, p. 343-374.

DELGADO, I. G (2015) Política industrial na China, na Índia e no Brasil: legados, dilemas de coordenação e perspectivas. Texto para Discussão № 2059. Brasília: IPEA

DELGADO, I. G. CONDÉ, E.S., ESTHER, A.B., SALLES, H.M. Cenários da Diversidade - variedades de capitalismo e política industrial nos EUA, Alemanha, Espanha, Coréia, Argentina, México e Brasil (1998-2008). Dados. Rio de Janeiro, 2010.

DELGADO, I. G. Previdência Social e Mercado no Brasil - a presença empresarial na trajetória da política social brasileira. São Paulo: LTr., 2001.

DELGADO, I.G. "Cidadania, Nação e Desenvolvimento: anotações esquemáticas a propósito de um Brasil golpeado, que renuncia a si mesmo". Revista Escuta, 2016. Disponível em https:// revistaescuta.wordpress.com/2016/08/25/cidadania-nacao-e-desenvolvimento-anotacoesesquematicas-a-proposito-de-um-brasil-golpeado-que-renuncia-a-si-mesmo/

EATWELL, J. A anatomia da "crise" da Previdência. Rio de Janeiro, Econômica, vol. 4, 2002.

FAGNANI, Eduardo. "O 'déficit' da Previdência e a posição dos juristas. In Texto para Discussão 305. Campinas. Instituto de Economia, 2017.

FAZIO, Luciano. A Previdência dos Servidores Civis da União: um diagnóstico. São Paulo: DIEESE, 2018.

FINELLO, Mariana, LEMOS, Pedro de Medeiros, FEIJÓ, Carmem. “Financeirização, empresas não financeiras e o ciclo econômico recente da economia brasileira". ANPEC, 2017. Disponível em https://www.anpec.org.br/sul/2017/submissao/files_l/i2-af45046d33e99e21282b1854208bb bd3.pdf Acesso em 15 jun. 2018.

G1. "Reforma da previdência dos militares: entenda a proposta ponto a ponto". G1, 2019. Disponível em https://glo.bo/2MZ38fG. Acesso em 28 abr. 2019

GENTIL, Denise, ARAÚJO, Eliane, PUTY, Cláudio, SILVA, Carlos. "Uma análise não convencional para o financiamento da Previdência Social no Brasil: aspectos teóricos e evidências empíricas?" In: Carlos Alberto Puty e a Denise Lobato Gentil. A Previdência Social em 2060: As inconsistências do modelo de projeção atuarial do governo brasileiro. Brasília: ANFIP/DIEESE; Plataforma Política Social, 2017.

GHANI, Alan. Entenda por que a Reforma da Previdência aumentará a renda e o emprego.

Disponível em Infomoney, 2019. Disponível em https://bit.ly/31AC1LV. Acesso em 27 abr. 2019.

HALL, Peter e SOSKICE, David. Varieties of Capitalism. Oxford: Oxford University Press, 2001.

HIRSCHMAN, Albert O. A retórica da intransigência: perversidade, futilidade, ameaça. São Paulo: Companhia das Letras, 1992.

MARSHALL, T.H. Cidadania, Classe Social e Status. Rio de Janeiro: Zahar, 1967.

MESA-LAGO, Carmelo. "A reforma estrutural dos benefícios de seguridade social na América Latina: modelos, características, resultados e lições", in Vera. S. P. Coelho (org.). A reforma da previdência social na América Latina. São Paulo: Editora FGV., 2003.

POLANYI, K. A Grande Transformação. Rio de Janeiro: Campus, 1980

PORTUGUESE.PEOPLE.CN Gasto da China em P\&D atinge 2, $1 \%$ do PIB em 2016. Disponível em https://bit.ly/2H4vPnM. Acesso em 30 abr. 2019.

PRADO, Eduardo. A llusão Americana. Brasília: Edições do Senado Federal, 2003. 
PUTY, Carlo Alberto, FRANCÊS, Carlo Renato, CARVALHO, Sólon, SILVA DA Marcelino, ALVES DA SILVA, Carlos. "Quão acuradas são as projeções financeiras e atuariais do Regime Geral de Previdência Social?" In: Carlos Alberto Puty e a Denise Lobato Gentil. A Previdência Social em 2060: As inconsistências do modelo de projeção atuarial do governo brasileiro. Brasília: ANFIP/ DIEESE; Plataforma Política Social, 2017.

PUTY, Carlos Alberto; GENTIL, Denise. "Introdução". In: Carlos Alberto Puty e a Denise Lobato Gentil. A Previdência Social em 2060: As inconsistências do modelo de projeção atuarial do governo brasileiro. Brasília: ANFIP/DIEESE; Plataforma Política Social, 2017.

SCHWARZER, H. "Algumas anotações sobre equívocos conceituais na discussão das reformas previdenciárias na América Latina". In; Debates. № 19-Reforma Previdenciária - Vetores do Debate Contemporâneo. São Paulo: Fundação Konrad Adenauer-Stiftung/Centro de Estudos, 1999.

TESOURO NACIONAL. Aspectos Fiscais da Previdência Social. Brasília: 2017. Disponível em: https://bit.ly/2KxINhd. Acesso em 13 jan. 2018.

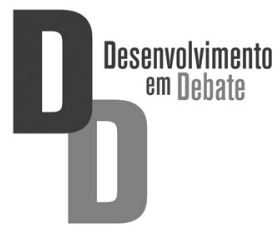

